JAMALI - Jurnal Abdimas Madani dan Lestari Vol. 01, Issue. 01, Maret 2019, Hal 18-23 (e-ISSN: - ; p-ISSN: - ) https://journal.uii.ac.id/JAMALI

\title{
Inisiasi Peningkatan Matematika Dasar dan Hafalan Al-Qur'an di Madrasah Diniyyah As-Salam
}

\author{
Asyharul Muala, Achmad Fauzan, Muthia Dishanur Izzati, Farhatun Nissa \\ Jurusan Statistika, Universitas Islam Indonesia, Yogyakarta, Indonesia \\ *Corresponding E-mail : achmadfauzan@uii.ac.id
}

\begin{abstract}
Cultivation of knowledge will be strong if given early, because as an illustration a tree will be sturdy if the roots have been hardened firmly embedded in the ground. But with roots that are not yet strong, the tree will easily be washed away by the existing water flow. Not a few children are uncontrolled because of this development, because of this, the dedication team designed a simple scheme to restore the nature of children so that they can be re-controlled by returning to the Qur'an. Besides that, his logical ability was honed by strengthening basic math skills. This service was carried out at the Madrasah Diniyyah As-Salam (Jalan Yudistira 104, Nglinggan, Wedomartani-Ngemplak, Sleman) which has been carried out for 6 months focusing on children in grades 4, 5 and 6. The hope of this service is to strengthen children's logical thinking. -children and create Qur'anic characters. The implementation of service is carried out regularly every Friday from 16.00 - 17.30 within 1 semester. The material is adapted to the material taught in the school so that it is measurable and useful for students. In the midst of the implementation, an examination was given to measure the extent of understanding the material given. Then at the end of the implementation a questionnaire was provided to measure the level of satisfaction and evaluation of the implementation of the service program. From the results of the overall questionnaire the students were very happy and it was hoped that this program would continue.
\end{abstract}

Keywords: Mentoring, Basic Mathematics, Al-Qur'an

\begin{abstract}
ABSTRAK
Penanaman ilmu akan kuat jika diberikan sejak dini, karena sebagai ilustrasi sebuah pohon akan kokoh jika akarnya sudah terpatri kuat menancap didalam tanah. Namun dengan akar yang belum kuat, pohon itu akan mudah hanyut tergerus arus air yang ada. Tidak sedikit anak-anak yang tidak terkontrol karena perkembangan ini, oleh karena hal tersebut tim pengabdian merancang skema sederhana untuk mengembalikan fitrah anak-anak supaya dapat kembali terkontrol yakni dengan kembali ke Al-Qur'an. Selain itu diasah kemampuan logikanya yakni dengan pemantapan kemampuan matematika dasar. Pengabdian ini dilakukan di Madrasah Diniyyah As-Salam (Jalan Yudistira 104, Nglinggan, Wedomartani-Ngemplak, Sleman) yang sudah dilakukan selama 6 bulan berfokus kepada anak-anak kelas 4, 5 dan 6. Harapan diadakannya pengabdian ini adalah penguatan kembali berpikir logis anak-anak serta menciptakan karakter yang Qur'ani. Pelaksanaan pengabdian dilaksanakan rutin setiap hari Jumat dengan dari pukul $16.00-17.30$ dalam kurun waktu 1 semester. Materi disesuaikan dengan materi yang diajarkan di sekolahan sehingga terukur dan berguna bagi peserta didik. Ditengah pelaksanaan diberikan ujian untuk mengukur sejauh mana pemahaman atas materi yang sudah diberikan. Kemudian diakhir pelaksanaan diberikan kuesioner untuk mengukur tingkat kepuasan serta evaluasi dari pelaksanaan program pengabdian. Dari hasil kuesioner secara keseluruhan peserta didik sangat senang dan diharapkan program ini tetap dapat diteruskan.
\end{abstract}

Kata Kunci: Pendampingan, Matematika Dasar, Al-Qur’an.

\section{PENDAHULUAN}

Banyak cara seorang anak memperoleh pendidikan, salah satunya dengan mengikuti sekolah islam sore atau yang lebih umum dikenal dengan nama Madrasah. Jika pesertanya masih Sekolah Dasar dinamakan Madrasah Diniyah. Apabila secara harfiah, Madrasah Diniyah adalah salah satu lembaga pendidikan keagamaan pada jalur luar sekolah yang diharapkan mampu secara menerus 
memberikan pendidikan agama Islam kepada anak didik yang tidak terpenuhi pada jalur sekolah yang diberikan melalui sistem klasikal serta menerapkan jenjang pendidikan.

Jenjang dalam Madrasah Diniyah terbagi atas 3 macam: (1) Diniyah Awaliyah yang menyelenggarakan pendidikan agama Islam tingkat dasar selama selama 4 (empat) tahun dan jumlah jam belajar 18 jam pelajaran seminggu, (2) Diniyah Wustho yang menyelenggarakan pendidikan agama Islam tingkat menengah pertama sebagai pengembangan pengetahuan yang diperoleh pada Madrasah Diniyah Awaliyah, masa belajar selama selama 2 (dua) tahun dengan jumlah jam belajar 18 jam pelajaran seminggu, dan (3) Diniyah Ulya yang menyelenggarakan pendidikan agama Islam tingkat menengah atas dengan melanjutkan dan mengembangkan pendidikan Madrasah Diniyah Wustho, masa belajar 2 (dua) tahun dengan jumlah jam belajar 18 jam per minggu (Departemen Agama, 1998).

Beragam nilai yang diajarkan di dalam Madrasah tersebut, yang sebagaimana umumnya adalah latihan membaca Al-Qur'an. Akan tetapi, masih cukup jarang yang memberikan pengabdian tambahan misalnya adalah menghafal Al-Qur'an maupun tambahan untuk materi pelajaran yang lain. Begitu pula yang ada di Madrasah Diniyah AS-Salam yang berada di daerah Sleman tersebut. Di Madrasah Diniyah As-Salam, siswa dibekali ilmu agama tiap hari khusunya bagaimana membaca AlQur'an.

Oleh karena itu, tim pengabdian untuk melakukan invoasi khususnya dalam hal hafalan AlQur'an dan tambahan pelajaran. Hafalan Al-Qur'an dilakukan guna memulai atau merintis anak untuk mencintai Al-Qur'an. Disamping itu, karena anak-anak yang diajarkan berumur kisaran 5-12 tahun lebih memiliki daya ingat yang lebih kuat dibanding kalau sudah berumur lanjut.

Hal ini senada dalam penelitian Kartono dalam Chussurur (2011) yang menjelaskan bahwasannya ingatan anak di usia 10-14 tahun mencapai intensitas paling besar, paling kuat, daya menghafal serta daya memorisasi yang berdampak anak mampu untuk meningat materi dalam jumlah paling banyak.

Selain itu, dengan perkembangan kemajuan teknologi dan informasi yang berkembang saat ini tidak sedikit menimbulkan dampak negative diantaranya kurangnya interaksi sosial, kecanduan handphone/gadget, bahkan depresi (Alghamdi, 2016). Hal ini senada juga dengan penelitian Muduli (2014) yang menyatakan semakin banyak penggunaan gadget semakin besar persentase dalam permasalahan pendengaran, logika berpikir, dan tingkat depresi.

Oleh karena itu inovasi penambahan pelajaran dilakukan sebagai selingan atau variasi supaya anak-anak tidak jenuh dalam pembelajaran dan tidak kecanduan gadget. Pada pengabdian ini direncanakan pengabdian berkaitan tentang mata pelajaran matematika untuk kelas 5 atau 6 sebagai bekal untuk persiapan menapaki jenjang pendidikan lebih tinggi.

\section{METODE}

Metoda yang digunakan dalam pengabdian ini adalah sebagai berikut.

a. Observasi lapangan

Dilakukan guna untuk mengetahui kondisi riil dari tempat pengabdian. Berdasarkan observasi tim pengabdian serta mengacu referensi, jarak madrasah ini dengan UII berkisar 15 menit.

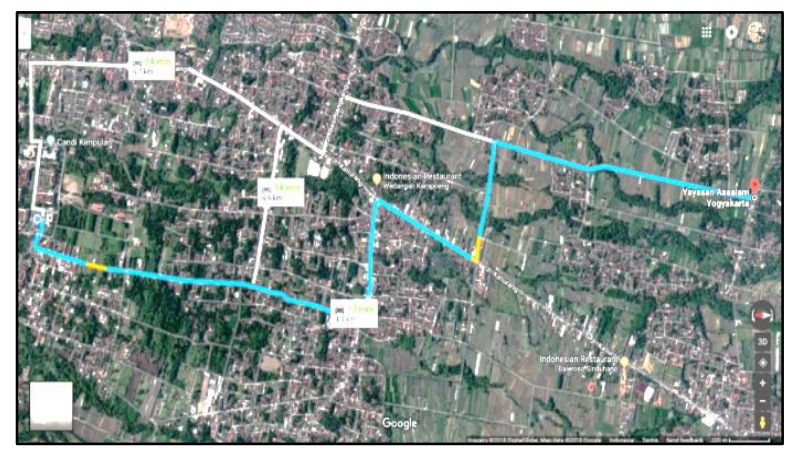

Gambar 1. Petak akses lokasi dengan kampus Universitas Islam Indonesia. 


\section{b. Kajian Pustaka}

Kajian pustaka dilaksanakan dengan mengkaji literatur materi-materi matematika yang ada di Sekolah Dasar (SD) dan juga variasi soal guna meningkatkan daya tarik siswa. Materi yang direncakan disesuaikan dengan Silabus Mata Pelajaran SD semester 1, yakni sebagai berikut.

\section{Kelas 5}

1. Bilangan Bulat

2. Pengerjaan Hitung Bilangan Bulat

3. Waktu.

Kelas 6

1. Operasi Hitung Bilangan Bulat

2. Pengukuran Volume perwaktu

3. Menghitung Luas.

c. Praktik langsung

Pelaksanaan pengabdian masyarakat dilaksanakan di Madrasah Diniyah As-Salam berada di bawah Yayasan As-Salam Yogyakarta. Madrasah Diniyah As-Salam berada dibawah Yayasan AsSalam Yogyakarta berkedudukan di Jalan

Yudistira 102 dusun Nglinggan Wedomartani Ngemplak Sleman Daerah Istimewa Yogyakarta. Praktik pembinaan dilaksanakan sebanyak 1-2 kali dalam 1 minggu (umumnya) yang dibantu juga dengan pihak madrasah yakni ustad/ustadzah di madrasah tersebut.

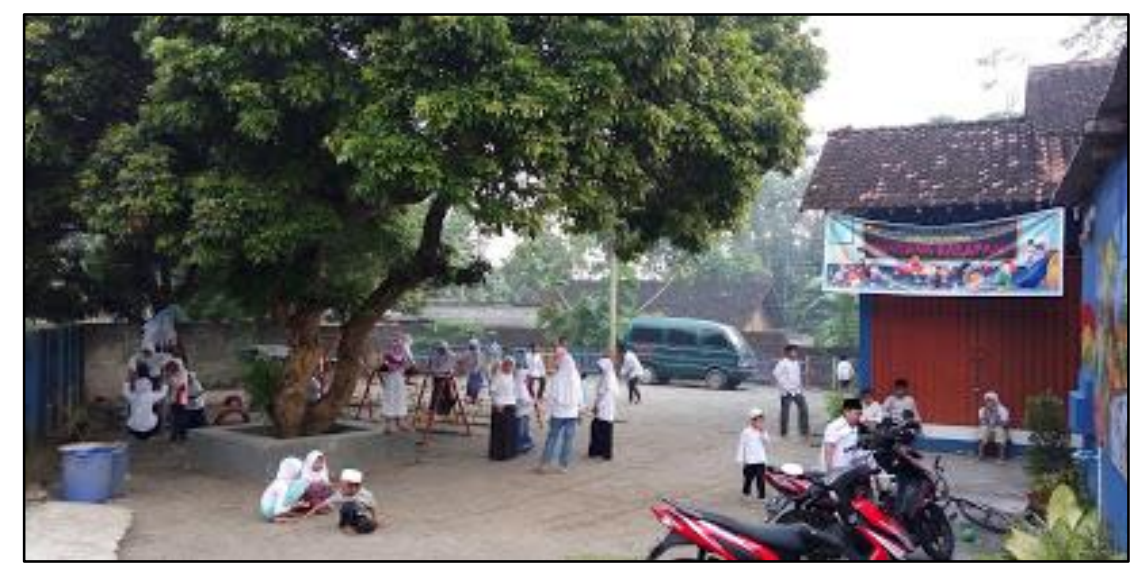

Gambar 2. Gambaran umum Madrasah Diniyah As-Salam

Pelaksanaan praktik langsung melibatkan mahasiswa khususnya mahasiswa program studi Statistika FMIPA Universitas Islam Indonesia (UII) angkatan 2015, 2016, dan 2017 dengan tujuan menambah pengalaman dan mengasah kemampuan mahasiswa tersebut. Kegiatan pembelajaran di Madrasah Diniyah As-Salam dimulai mulai pukul 16.00 sampai 17.30 yang berorientasi terhadap cara membaca Al-Qur'an.

d. Penyusunan masterplan berjangka

Penyusunan berjangka dilaksanakan dengan tujuan program pembinaan ini tidak berhenti ketika program pengabdian ini nantinya selesai. Salah satu penyusunan disini adalah pembuatan latihan soal yang nantinya dapat digunakan pada generasi berikutnya.

\section{HASIL DAN PEMBAHASAN}

Pelaksanaan pembinaan dilakukan setiap hari Jumat jam 16.00 sampai 17.30 WIB di ruang kelas Madrasah Diniyyah As-Salam di Jalan Yuistira 104 Dusun Nglinggan Desa Wedomartani Kecamatan Ngemplak Kabupaten Sleman Provinsi Daerah Istimewa Yogyakarta (DIY) 
Kegiatan ini dilaksanakan dalam kurun waktu enam (6) bulan, adapun perinciannya adalah pada Tabel 1.

Tabel 1. Rencana Kegiatan Pengabdian

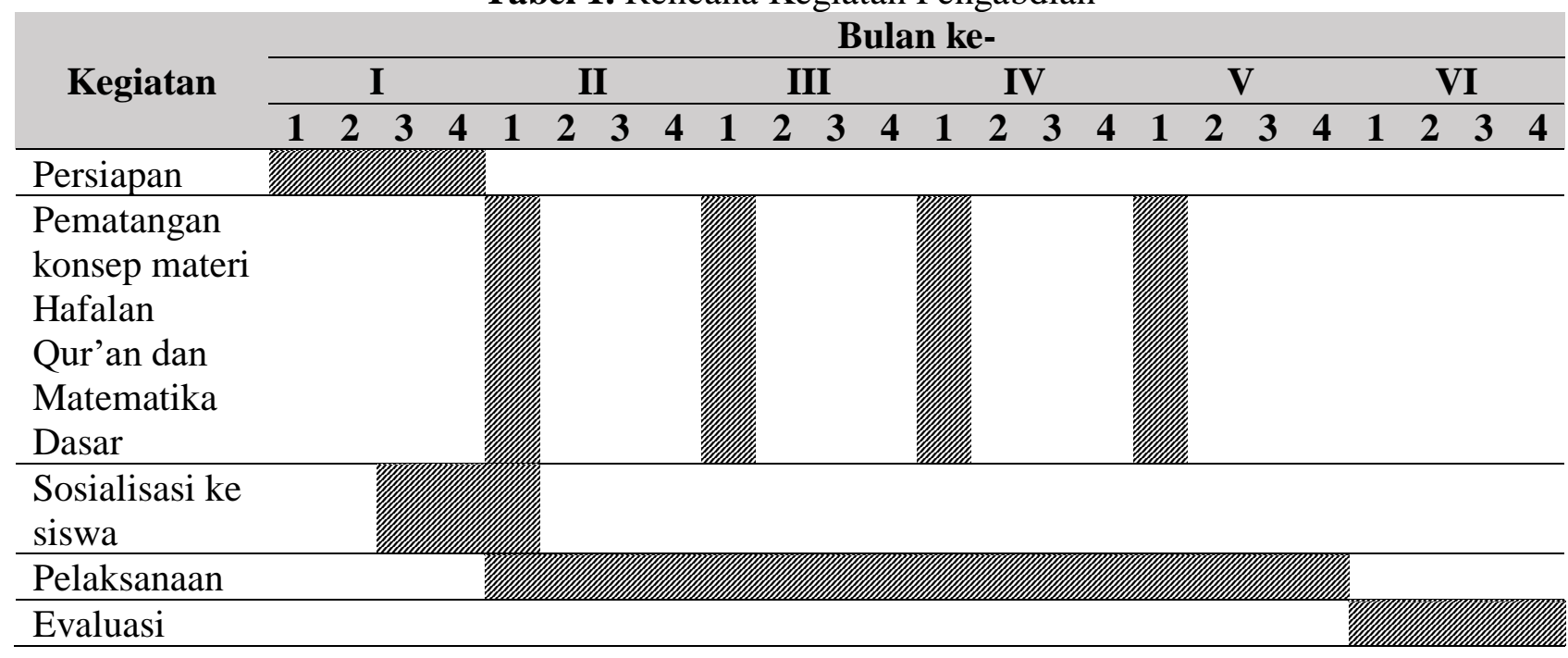

Siswa yang dibina adalah anak-anak kelas IV, V, dan VI total sebanyak 20 siswa. Sebelum pembinaan rutin dilakukan, dilaksanakan ujian pretest terlebih dahulu dan secara berjangka dilakukan ujian evaluasi serta ujian posttest untuk mengukur kemampuan siswa. Dan sesuai dengan yang direncanakan, pembinaan dilaksanakan setiap satu kali dalam seminggu. Didasarkan luaran pengabdian, maka disajikan pada Tabel 2.

Tabel 2. Kesesuaian hasil pelaksanaan dengan target luaran.

\begin{tabular}{|c|c|c|}
\hline No & Target Luaran & Hasil Pelaksanaan \\
\hline 1 & $\begin{array}{l}\text { Peningkatan kualitas pada peserta didik dengan indikator } \\
\text { adanya peningkatan nilai dari ujian pertama dan ujian } \\
\text { berikutnya }\end{array}$ & $\begin{array}{l}\text { Terlaksana. } \\
\text { Akan tetapi terdapat kendala dalam hal } \\
\text { memperoleh nilai ujian pertama dan } \\
\text { kedua, sebagai alternatifnya } \\
\text { dilaksanakan ujian sendiri yang hasilnya } \\
\text { positif. }\end{array}$ \\
\hline 2 & $\begin{array}{l}\text { Peningkatan jumlah hafalan peserta didik yang dilakukan } \\
\text { secara bertahap dengan indkator adalah banyaknya } \\
\text { hafalan yang sudah dimiliki oleh peserta didik. }\end{array}$ & $\begin{array}{l}\text { Terpenuhi. } \\
\text { Dibuktikan dengan awalnya } 7 \text { surat } \\
\text { menjadi } 18 \text { surat }\end{array}$ \\
\hline 3 & $\begin{array}{l}\text { Kontribusi akademik bagi mahasiswa adalah dapat } \\
\text { berlatih dalam hal mengajar serta melatih kemampuan } \\
\text { sosial untuk persiapan kedepannya. }\end{array}$ & $\begin{array}{l}\text { Terpenuhi. } \\
\text { Dibuktikan dari observasi minimal dari } \\
\text { perkembangan cara berkomunikasi } \\
\text { mahasiswa dan pemahaman mahasiswa. } \\
\text { Selain itu dengan peningkatan kapasitas } \\
\text { penguatan untuk terjun langsung ke } \\
\text { lapangan dalam rangka proses } \\
\text { pengabdian. }\end{array}$ \\
\hline 4 & $\begin{array}{l}\text { Laporan pengabdian masyarakat sebagai bentuk } \\
\text { pertanggungjawaban pelaksanaan. }\end{array}$ & $\begin{array}{l}\text { Terpenuhi. } \\
\text { Dibuktikan dengan terselesaikannya } \\
\text { laporan dan terselesaikannya kegiatan } \\
\text { pengabdian sesuai waktu dan rencana } \\
\text { yang disusun. }\end{array}$ \\
\hline 5 & $\begin{array}{l}\text { Penguatan visi misi dari Universitas Islam Indonesia } \\
\text { (UII) }\end{array}$ & $\begin{array}{l}\text { Terlaksana. } \\
\text { Minimal dari sisi dakwah islamiah dan } \\
\text { UII menyebarkan manfaat UII kepada } \\
\text { masyarakat. }\end{array}$ \\
\hline
\end{tabular}


Sesuai dengan yang direncanakan, pengabdian berjalan setiap Jumat sore untuk pembinaan matematika, begitu juga untuk pelaksanaan hafalan. Sebagai gambaran umum, disajikan pada Gambar 3
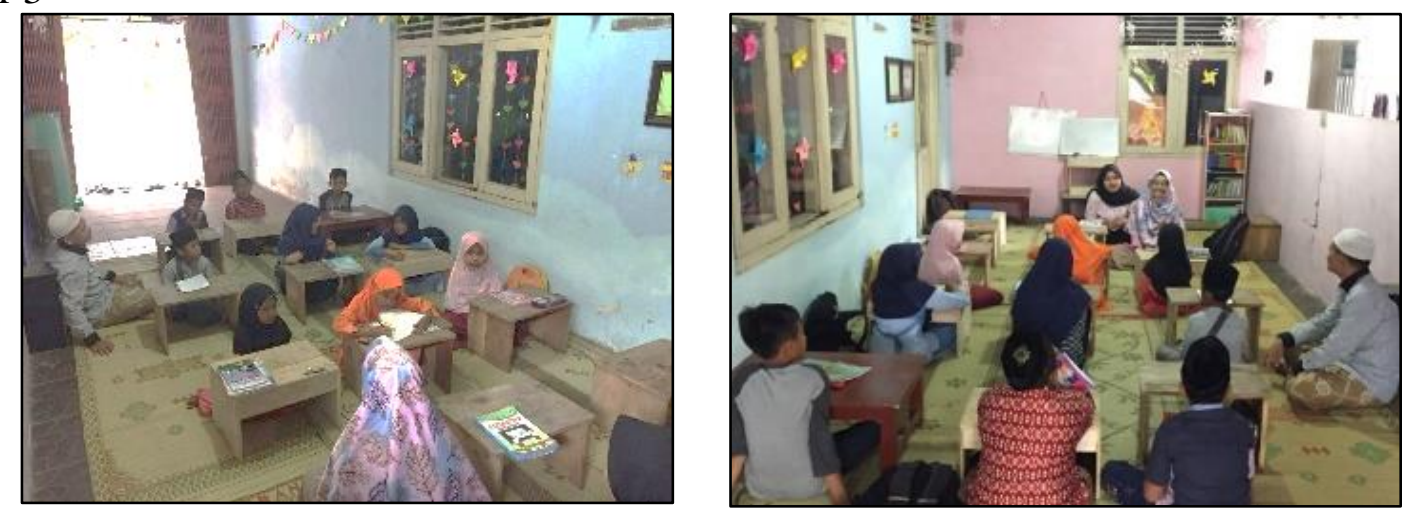

Gambar3.Gambaran umum pelaksanaan pengabdian.

Disetiap pertemuan diberikan materi (lampiran), latihan soal, dan ujian. Diakhir proses pengabdian diberikan kuesioner terkait proses pelaksanaan pengabdian. Adapun hasil yang diperoleh disajikan pada Gambar 4

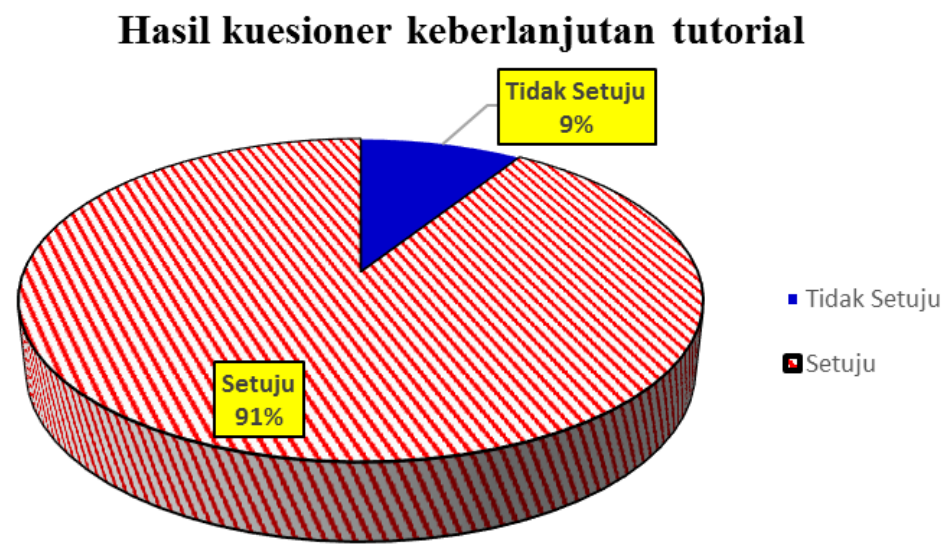

Pie chart di atas menggambarkan tentang persentase darı kelanjutan kegiatan tutor yang diadakan di Madrasah Diniyyah As-Salam. Berdasarkan pie chart, diketahui ada 88,9\% anak didik yang mengingikan tutor tetap diadakan, yang berarti ada 8 dari 9 orang anak didik yang menginginkan tutor tetap diadakan. Kemudian diperinci dengan penjabaran masing-masing kuesioner (faktor-faktor dilakukannya keberlanjutan tutorial), yakni pada Gambar 5.

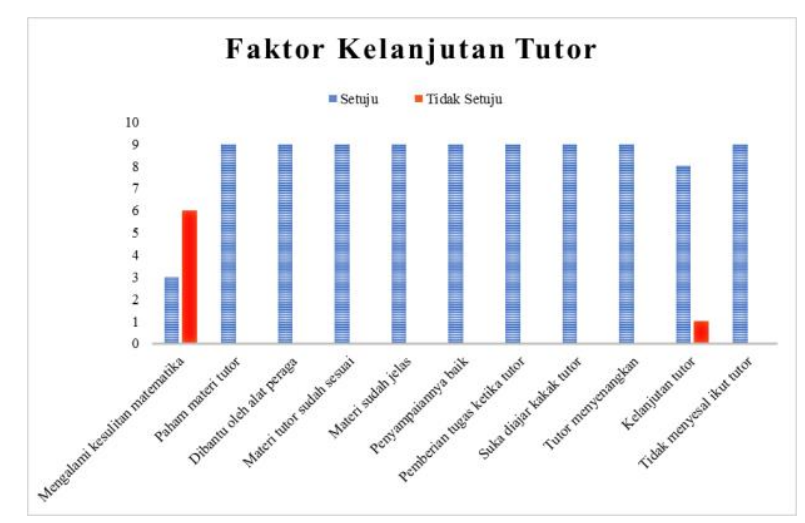

Gambar 5. Faktor kelanjutan tutor 
Adapun faktor-faktor yang mendukung kegiatan tutor ini adalah karena anak didik merasa kesulitan dalam belajar matematika. Kemudian dengan adanya alat peraga yang digunakan ketika tutor, materi yang disampaikan sudah sesuai, jelas dan baik, pemberian tugas ketika tutor kepada anak didik, mereka senang diajar kakak tutor sehingga membuat tutor menjadi menyenangkan, dan tidak menyesal mengikuti kegiatan tutor yang diadakan setiap satu minggu sekali di hari Jum'at.

Kendati demikian, terdapat beberapa kendala dan solusi dalam pelaksanaan disajikan pada Tabel 3.

Tabel 3. Kendala dan solusi dalam pelaksanaan

\begin{tabular}{lll}
\hline No & \multicolumn{1}{c}{ Kendala } & \multicolumn{1}{c}{ Solusi } \\
\hline 1 & $\begin{array}{l}\text { Dikarenakan anak didik yang dibina berasal dari } \\
\text { sekolah yang berbeda beda menyebabkan cukup } \\
\text { sulit untuk menyamakan materi. }\end{array}$ & $\begin{array}{l}\text { Diberikan materi yang sebagian besar } \\
\text { representative dari populasi, apabila } \\
\text { dimungkinkan bergilir materi yang } \\
\text { diberikan. }\end{array}$ \\
\hline 2 & $\begin{array}{l}\text { Kurang semangat karena sudah sore dan tenaga } \\
\text { siswa sudah habis karena seharian sudah belajar } \\
\text { disekolah. }\end{array}$ & $\begin{array}{l}\text { Diberikan motivasi diawal pelaksanaan } \\
\text { serta belajar dengan menyenangkan. }\end{array}$ \\
\hline 3 & Kemampuan daya hafal yang berbeda-beda. & $\begin{array}{l}\text { Diberikan tambahan waktu ekstra bagi } \\
\text { peserta didik yang kurang mampu } \\
\text { mengikuti penambahan hafalan }\end{array}$ \\
\hline
\end{tabular}

\section{KESIMPULAN}

Berdasarkan luaran pengabdian dan hasil pelaksanaan, diperoleh simpulan sebagai berikut.

1. Secara keseluruhan pelaksanaan pengabdian berjalan sesuai dengan indikator yang direncakan, diantaranya banyaknya hafalan yang meningkat serta kemampuan akademik peserta didik khususnya dalam bidang matematika.

2. Berdasarkan kuesioner yang diberikan, diadakannya program ini menjadikan inovasi atau ragam dari pembinaan di Madrasah dan anak-anak merasa senang serta diharapkan dapat dilanjutkan kedepannya.

3. Kendati sudah berjalan lancar, perlu direncakan lebih matang seperti halnya materi maupun sistem evaluasi yang dilaksanakan.

\section{DAFTAR PUSTAKA}

[1] Alghamdi,Yasser.2016. Negative Effects of Technology on Children of Today. Oakland University.

[2] As-Salam, I. Y. (n.d.). Profil Yayasan As-Salam Yogya. Retrieved August 9, 2018, from Yayasan As-Salam Yogya: http://assalamjogja.blogspot.com/p/tentang-kami.html

[3] Chussurur, M., Hidayat, T., \& Agustin, R. W. (2011). Pengaruh Pemberian Cerita Melalui Media Audiovisual Terhadap Recall Memory pada Anak-anak kelas V Sekolah Dasar Takmirul Islam Surakarta.

[4] Departemen Agama. (1998). Sejarah Perkembangan Madrasah. Direktorat Jendral Pembinaan Kelembagaan Agama Islam.

[5] Muduli,J.Ranjan. 2014. Addiction to Technological Gadgets and Its Impact on Health and Lifestyle: A Study on College Students. Thesis: National Institute of Technology, Rourkela 769008. India 